\title{
IMPACTOS URBANOS EM ÁGUAS SUBTERRÂNEAS -BACIA DA LAGOA DA PAMPULHA, BELO HORIZONTE-MG
}

\author{
Décio A. C. Beato ${ }^{1}$ \\ Marcelo J. Medeiros ${ }^{2}$ \\ Michael G.P. Drews ${ }^{3}$ \\ Georgete M. Dutra ${ }^{4}$
}

\begin{abstract}
RESUMO
Os recursos hídricos da bacia da lagoa da Pampulha estão sujeitos aos diversos impactos ambientais decorrentes da urbanização desordenada, infra-estrutura de saneamento precária, erosão e assoreamento, desmatamento irregular e disposição inadequada de resíduos sólidos e de efluentes industriais. As conseqüências se refletem na lagoa com o assoreamento e a eutrofização. O sistema aqüífero, responsável pela manutenção do escoamento de base dos tributários da lagoa, também sofre as conseqüências do tipo de ocupação com a alteração do regime de escoamento das nascentes e da qualidade das águas subterrâneas rasas. Com o modelo de urbanização atual, o terreno é densamente ocupado sem infra-estrutura de saneamento eficiente e áreas de preservação dos recursos hídricos, causando o desmatamento das matas ciliares, a impermeabilização do solo e a degeneração das águas superficiais e subterrâneas, principalmente, por efluentes domésticos. O diagnóstico hidrogeológico procurou estabelecer o modelo hídrico subterrâneo, além de dimensionar as variáveis hidroquímicas e hidrodinâmicas, sugerindo áreas de preservação ou de ocupação restrita. A preservação dos recursos hídricos se justifica pela importância sócio-cultural que a lagoa exerce na comunidade, além da manutenção das disponibilidades hídricas locais.
\end{abstract}

Palavras-Chave: Recursos hídricos; hidrogeologia urbana; contaminação hídrica urbana.

\begin{abstract}
The water resources of the basin of the Pampulha Lake are subject to various environmental impacts from unplanned urbanization, precarious sanitation infrastructure, erosion and silting, irregular deforestation and inadequate disposal of solid residue and industrial effluents. The consequences are reflected in the lake, with silting and eutrophication. The aquifer system responsible for maintaining the base drainage of the tributaries to the lake also suffers the consequences of the type of occupation, with the alteration of the drainage system of the sources and the quality of shallow underground water. With the current urbanization model, the land is densely occupied without efficient sanitary infrastructure and areas for the preservation of water resources, bringing about the cutting down of waterway vegetation, the increasing impermeability of the soil and the degeneration of surface and underground water, mainly by domestic effluents. The hydro-geological diagnostic sought to establish an underground water model, as well the hydro-chemical and hydro-dynamic variables, suggesting areas of preservation or controlled occupation. The preservation of water

\footnotetext{
${ }_{2}^{1}$ Hidrogeólogo; décio@cprmbh.gov.br.

2 Engenheiro Hidrólogo; mjmedeiros@cprm.gov.br.

${ }^{3}$ Geofísico: CPRM-Serviço Geológico do Brasil/SUREG BH, Av. Brasil 1731. CEP 30140-002. Belo Horizonte; MG; Brasil - (31) 3261-0415; drews@cprmbh.gov.br.

${ }^{4}$ Geóloga Fundação Gorceix, Av Brasil 1731. CEP 30140-002. Belo Horizonte; MG; Brasil - (31) 3261-0415; georgete@cprmbh.gov.br.
} 
resources is jusfied by the socio-cultural importance the lake has in the community, as well as the maintenance of the availability of local waters.

\section{INTRODUÇÃO}

O diagnóstico hidrogeológico da bacia da Lagoa da Pampulha foi uma iniciativa da Secretaria Municipal de Meio Ambiente de Belo Horizonte que estabeleceu convênio com a Companhia da Pesquisa de Recursos Minerais-CPRM, com atribuições de Serviço Geológico do Brasil, para elaborar os estudos pertinentes entre setembro de 2000 e junho de 2001.

O objetivo foi definir o modelo hidrogeológico da bacia de contribuição da Lagoa da Pampulha, de maneira a avaliar os impactos da ocupação urbana e sugerir medidas para preservação dos recursos hídricos, tanto subterrâneos como superficiais. Neste artigo resumimos os dados e informações do Estudo Hidrogeológico da Bacia da Lagoa da Pampulha (Beato et al., 2001).

A Lagoa é uma importante referência cultural e de lazer da comunidade, e atualmente é um ícone no resgate das mazelas da ocupação urbana desordenada. Diversos são os problemas identificados em sua degradação. Os principais estão fora da orla e tem origem na ignorância em relação aos efeitos de pequenas atitudes, a principio sem grande alcance, mas seqüenciadas, relacionadas com: ocupação urbana desordenada, desmatamento das margens e cabeceiras dos córregos, decapeamento do solo com fins especulativos e até estéticos, disposição inadequada de resíduos sólidos, redes de esgoto clandestinas com lançamento nos cursos d'água, entre outros. Alguns problemas são estruturais e relacionados com precárias condições de saneamento e de fiscalização no cumprimento da legislação ambiental, e com falta de eficientes programas de educação ambiental.

\section{ÁREA DE ESTUDO}

A bacia hidrográfica da Lagoa tem área de $97,91 \mathrm{~km}^{2}$, delimitada pelas coordenadas UTMs N 78079/77940 e E 5950/6087, situada na região metropolitana de Belo Horizonte, MG (figura 1). Parte se encontra em Belo Horizonte $\left(43,97 \mathrm{~km}^{2}\right)$ e parte no município de Contagem $(53,94$ $\mathrm{km}^{2}$ ).

A represa foi construída em 1938 com a função de abastecimento e lazer da população de Belo Horizonte. Atualmente tem a finalidade de amortecer as enchentes nas áreas a jusante, onde se encontram diversos bairros e o aeroporto da Pampulha, além de compor o cenário paisagístico do Complexo Arquitetônico de Oscar Niemayer, tombado pelo Patrimônio Nacional. A capacidade original de armazenamento, a partir da sua reconstrução em 1954 era de $18 \times 10^{6} \mathrm{~m}^{3}$, atualmente está reduzida a 8,5 $x 10^{6} \mathrm{~m}^{3}$ (CDTN, 2000), ocupando uma superfície de $2,08 \mathrm{~km}^{2}$. A lamina d'água é rasa devido ao assoreamento, atingindo $14,0 \mathrm{~m}$ nas proximidades do vertedouro.
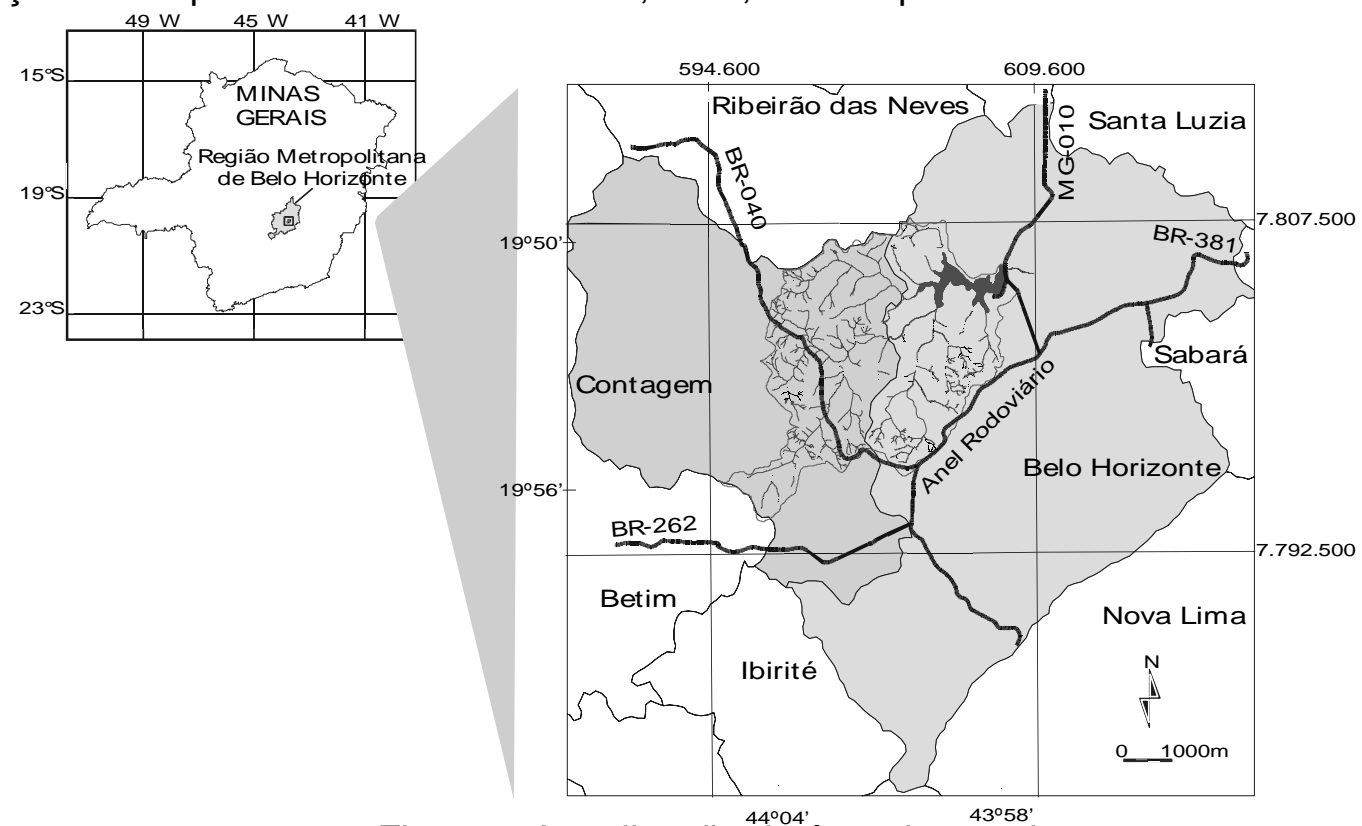

Figura 1: Localização da área de estudo. 
A vegetação original era do tipo transição entre cerrado e mata tropical. Atualmente predominam pastagens $\mathrm{e}$ cerrado degradado com vestígios da mata original ou em estágio avançado de regeneração.

A urbanização ocupava, em 1995, $42,7 \%$ da área ou $41,76 \mathrm{~km}^{2}$, onde residem cerca de 330.000 habitantes. Nas 36 vilas e favelas habitam perto de 50.000 habitantes.

Cerca de $70 \%$ da população situa-se entre as faixas de baixa a muito baixa renda. Em certas áreas, a qualidade de vida precária, carente de infra-estrutura de saneamento básico, resulta em elevado índice de mortalidade infantil, cerca de 65 óbitos/1.000 nascidos (PROPAM, 1999).

O abastecimento de água atende quase toda a população e o esgotamento sanitário tem cobertura parcial com prioridade para os bairros adensados. Até 1992, 59 bairros de Contagem lançavam seus esgotos diretamente nos tributários da represa da Pampulha (Peixoto e Ávila, 1992).

A partir da década de 60 a ocupação urbana teve crescimento desordenado, causando a degeneração na qualidade das águas da represa e na sua capacidade de armazenamento. Em 1979 foi necessária a dragagem da Lagoa, retirando $2,2 \times 10^{6} \mathrm{~m}^{3}$ de sedimentos depositados em uma ilha erguida na enseada do córrego Ressaca (SUDECAP, 1989). Na década de 90 foi caracterizado o processo de eutrofização da represa. Em 2002 está previsto o inicio da retirada de $4,0 \times 10^{6} \mathrm{~m}^{3}$ de sedimentos e construção da Estação de Tratamento de Efluentes com interceptação e tratamento dos efluentes das sub-bacias Ressaca e Sarandi.

\section{ASPECTOS HIDROLÓGICOS CLIMATOLÓGICOS}

A Lagoa deságua no ribeirão Pampulha, integrante da bacia do ribeirão do Onça, afluente do rio das Velhas. São tributários diretos os córregos Olhos d'Água, AABB, Baraúna, Água Funda, Tijuco, Mergulhão, Sarandi e Ressaca. Os dois últimos são os principais, contribuindo com cerca de $70 \%$ do volume de água e representam $63 \%$ da área total de drenagem.

A vazão específica média da Bacia, em áreas pouco urbanizadas, é de 25 $\mathrm{L} / \mathrm{s} / \mathrm{km}^{2}$. A vazão efluente média da Lagoa é da ordem de $1,6 \mathrm{~m}^{3} / \mathrm{s}$ (SUDECAP, 1999), considerando que o período monitorado foi curto e as medidas estavam sujeitas às interferências do efeito regularizador da barragem, aporte de efluentes, impermeabilização do solo e assoreamento das calhas fluviais.

Em estudos realizados pelo PROSAM (1996), estimava-se que em 1998 a vazão de esgoto doméstico lançado na Bacia seria da ordem de 609,91 L/s, o que gera alteração significativa no regime de vazões naturais da maioria dos cursos d'água afluentes à lagoa.

O clima da região, segundo a classificação de Köppen é Cwa - tropical de altitude com inverno seco e verão chuvoso. A temperatura média anual é de $21,5^{\circ} \mathrm{C}$ e a precipitação média anual de $1.479,5 \mathrm{~mm}$. A evapotranspiração $\mathrm{ET}_{0}$, calculada pelo método de Penman, é de 1.404,8 mm.

O balanço hídrico indica que o período de deficiência hídrica estende-se de maio a outubro, sendo que os maiores déficits ocorrem em agosto. De outubro a dezembro ocorre o início do período chuvoso. O excedente hídrico ocorre a partir de dezembro, estendendo-se até março.

A capacidade de campo, determinada a partir do tipo de solo e do mapa de uso e ocupação do solo de 1995, resultou em $150 \mathrm{~mm}$. Um suposto aumento de $47 \%$ da área urbana resultou em uma capacidade de campo de $100 \mathrm{~mm}$. As duas simulações do balanço são apresentadas na tabela 01.

Com o aumento da urbanização ocorre a diminuição da ER e o aumento da DEF e da EXC. Assim, a redução da área permeável da Bacia, diminui a infiltração, aumenta o escoamento superficial durante o período chuvoso e reduz o armazenamento de água no solo, necessário para a manutenção de vazões mínimas no período seco.

Um dos maiores danos ambientais à Lagoa é o assoreamento. Segundo Oliveira e Baptista (1997) de 1957, data da reconstrução da barragem, até 1994, ocorreu um aporte de cerca de $8.800 .000 \mathrm{~m}^{3}$ de sedimentos. A figura 2 mostra a perda de volume de reservação da Lagoa.

Os principais problemas que geram erosão e assoreamento são: remoção ilegal da mata ciliar e inadequada do solo para loteamentos e instalações industriais, ocupação de vertentes com alta declividade e disposição clandestina de "bota fora" ao 
longo de ruas, avenidas e canais. O tipo de solo homogêneo, areno-argiloso a argiloarenoso da decomposição de rochas de composição granítica, favorece a erosão, principalmente quando a cobertura vegetal é retirada.

Tabela 01: Balanço hídrico para capacidades de campo de 150 e 100 mm.

\begin{tabular}{c|c|c|c|c|c|c|c|c}
\hline \multicolumn{2}{l|}{} & \multicolumn{3}{|c|}{$\mathbf{1 5 0 \mathbf { m m }}$} & \multicolumn{3}{|c}{$\mathbf{1 0 0 \mathbf { m m }}$} \\
\hline Ano & $\begin{array}{c}\mathbf{P} \\
\mathbf{m m}\end{array}$ & $\begin{array}{c}\text { EP } \\
\mathbf{m m}\end{array}$ & $\begin{array}{c}\text { ER } \\
\mathbf{m m}\end{array}$ & $\begin{array}{c}\text { DEF } \\
\mathbf{m m}\end{array}$ & $\begin{array}{c}\text { EXC } \\
\mathbf{m m}\end{array}$ & $\begin{array}{c}\text { ER } \\
\mathbf{m m}\end{array}$ & $\begin{array}{c}\text { DEF } \\
\mathbf{m m}\end{array}$ & $\begin{array}{c}\text { EXC } \\
\mathbf{~ m m}\end{array}$ \\
\hline 1997 & 1.509 & 1.416 & 1.153 & 263 & 348 & 1.120 & 296 & 389 \\
1998 & 1.308 & 1.409 & 1.088 & 321 & 234 & 1.043 & 366 & 264 \\
1999 & 1.436 & 1.402 & 1.006 & 396 & 416 & 959 & 443 & 477 \\
2000 & 1.420 & 1.379 & 998 & 381 & 422 & 952 & 427 & 468 \\
\hline
\end{tabular}

Nota: P-precipitação, EP-evapotranspiração potencial, ER-evapotranspiração real, DEF-deficiência e EXCexcedência hídrica.

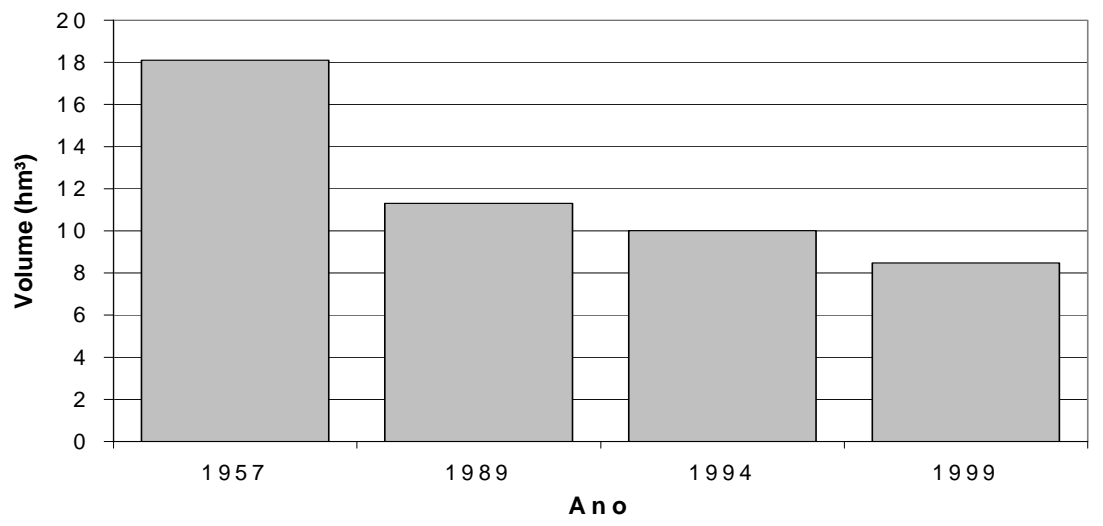

Figura 2: Variação do volume de reservação da Lagoa.

Fonte 1999: CDTN (2000).

A área total de solo exposto na bacia corresponde a $4,26 \mathrm{~km}^{2}$ (4,4 \% da área total), sendo que a sub-bacia do córrego Sarandi contém $74 \%$ do total e em Contagem estão 80 \% dessas áreas.

\section{ESTUDO \\ MATERIAIS E MÉTODOS DE}

O tratamento dos dados seguiu os padrões dos trabalhos executados pela CPRM que utilizou técnicos, procedimentos, equipamentos e aplicativos específicos.

Para a elaboração dos mapas temáticos utilizou-se bases digitais, fotografias aéreas (1:8.000), imagens de satélite Landsat 5 (banda 3) e Ikonos II (pancromática e multiespectral) que auxiliaram na interpretação geológica e na atualização parcial do uso e ocupação do solo.

O mapa geológico foi adaptado de Silva et al. 1994 (escala 1:25.000). As informações climatológicas e hidrológicas tiveram base em dados do CDTN, SUDECAP e DNMET.

O inventário hidrogeológico cadastrou praticamente todos os poços tubulares e nascentes, os poços escavados foram identificados por amostragem. Levantaramse as características físicas e construtivas dos pontos d'água, vazões, níveis, uso e fontes potenciais de poluição, além do $\mathrm{pH}$, $\mathrm{CE}$ e temperatura, utilizando-se equipamentos portáteis de precisão WTW Multiline P3 pH/LF-Set.

Ensaios de permeabilidade foram realizados com objetivo de caracterizar a capacidade de infiltração do solo. Utilizou-se o método de carga variável na zona nãosaturada (ABGE, 1996).

Ensaios geoelétricos de Caminhamento Elétrico Dipolo-Dipolo e Sondagem Elétrica Vertical - SEV foram realizados para detectar plumas de contaminação nos aterros sanitários. 
O estudo hidroquímico das águas superficiais e subterrâneas utilizou 15 e 28 amostras, respectivamente. Os parâmetros analisados in loco foram temperatura, $\mathrm{pH}$, Eh, CE e O.D., em laboratório foram: cor, turbidez, sólidos fixos, ST, STD, dureza total, tensoativos (ABS), fenóis, Namoniacal, N-orgânico, $\mathrm{NO}_{2}, \mathrm{NO}_{3}, \mathrm{HCO}_{3}, \mathrm{Cl}$, $\mathrm{SO}_{4}, \mathrm{Ca}, \mathrm{Mg}, \mathrm{Na}, \mathrm{K}, \mathrm{Fe}, \mathrm{Mn}, \mathrm{S}^{-2}, \mathrm{~F}, \mathrm{PO}_{4}, \mathrm{Al}$, $\mathrm{As}, \mathrm{Ba}, \mathrm{Cd}, \mathrm{Ni}, \mathrm{Pb}, \mathrm{Cu}, \mathrm{Cr}, \mathrm{Se}, \mathrm{Zn}, \mathrm{Ti}$, coliformes totais, coliformes fecais e estreptococos fecais. Para as análises de águas superficiais foram incluídos DBO, $\mathrm{Hg}$ e óleos e graxas.

As águas superficiais foram amostradas nos principais tributários da Lagoa e afluentes com e sem carga contaminante. Águas subterrâneas foram amostradas considerando a representatividade em relação às diversas condições de captação e riscos de contaminação.

O zoneamento do uso e ocupação do solo utilizou fotografias aéreas (1:8.000) de 1994 e 1995. As classes foram: Cobertura vegetal arbórea, herbácea e arbustiva, solo exposto e área urbana.

A delimitação das áreas de preservação dos recursos hídricos considerou aspectos legais, risco de assoreamento dos cursos de água e da Lagoa, e do comprometimento de recarga dos aqüíferos.

\section{GEOLOGIA}

A área está no contexto geológico do Cráton São Francisco, com ocorrência de rochas de composição granítica, diques de composições variadas e coberturas quaternárias.

As rochas de composição granítica (granitos, gnaisses e migmatitos) do Complexo Belo Horizonte (Noce et al., 1994), são de idade arqueana e ocupam a maior parte da Bacia.

Enxames de diques máficos proterozóicos alterados, de coloração avermelhada cortam as rochas graníticas com orientação predominante N50-70W. Possuem mergulho de alto ângulo, espessuras de dezenas de metros e comprimentos de alguns quilômetros. São constituídos de augita, plagioclásio, ilmenita, quartzo, titanita, apatita e biotita.

Diques clásticos são esporádicos e preenchem fraturas verticais a subverticais com orientação preferencial E-NE. Possuem extensão de dezenas de metros e largura de até $10 \mathrm{~m}$. O material de preenchimento é um arenito róseo-amarelado com fragmentos de quartzo e feldspato.

O solo residual é rico em areia, silte e argila, com baixa coesão. Espessuras de solo residual e rocha alterada podem atingir até $120 \mathrm{~m}$ (ponto 218, figura 3).

Os depósitos aluvionares ocorrem ao longo dos vales dos principais cursos d'água com espessuras de alguns metros. Predominam camadas areno-argilosas e argilo-arenosas.

Os fraturamentos possuem direção preferencial N10-30W e N50-70E e mergulho de alto ângulo. As fraturas abertas são as de direção NE-SW confirmada pelo preenchimento de diques clásticos. As fraturas NW-SE são preenchidas pelos diques máficos.

O relevo é caracterizado por colinas de topo plano a arqueado, encostas formando anfiteatros de declividade média a suave e vales amplos com drenagens pouco encaixadas. Predominam vales em terrenos de declividade muito baixa $(<10 \%)$ e as encostas possuem declividade baixa (10 a $20 \%$ ). Declividades moderadas a muito alta (>20\%) ocorrem em áreas restritas e onde ocorrem os principais problemas erosivos devido ao elevado gradiente e pequeno desenvolvimento pedológico.

As altitudes variam de $800 \mathrm{~m}$ na represa a $1.010 \mathrm{~m}$ no extremo sudoeste, próximo às nascentes do córrego Sarandi.

\section{HIDROGEOLOGIA}

Os aqüíferos são do tipo fraturado livre a semiconfinado nas rochas sãs do Complexo Belo Horizonte e granulares livres nos sedimentos aluvionares e solo residual dos granitóides (figura 3).

O sistema aqüífero fraturado restringe-se às zonas de fraturas das rochas do substrato ampliado pelo espesso manto de intemperismo que 0 recobre. Os fraturamentos de direção NE são os mais favoráveis à circulação de águas subterrâneas. Já os de direção NW são fraturas preenchidas por diques básicos e com menor permeabilidade.

O aqüífero fraturado apresenta vazão específica média de $0,16 \mathrm{~m}^{3} / \mathrm{h} / \mathrm{m}$. Poços que captam água do solo residual apresentaram, em média, o dobro da vazão específica $\left(0,36 \mathrm{~m}^{3} / \mathrm{h} / \mathrm{m}\right)$. 
Rev. Águas Subterrâneas nํㅜ 17/ Maio 2003.

Os aqüíferos granulares ocorrem nos semiconfinados com espessuras de até 100 sedimentos colúvio-aluvionares e, $\mathrm{m}$ no solo residual (média de $52,7 \mathrm{~m}$ principalmente, no solo residual, ou elúvio, considerando solo+elúvio+saprólito) do substrato rochoso. São aqüíferos livres a 


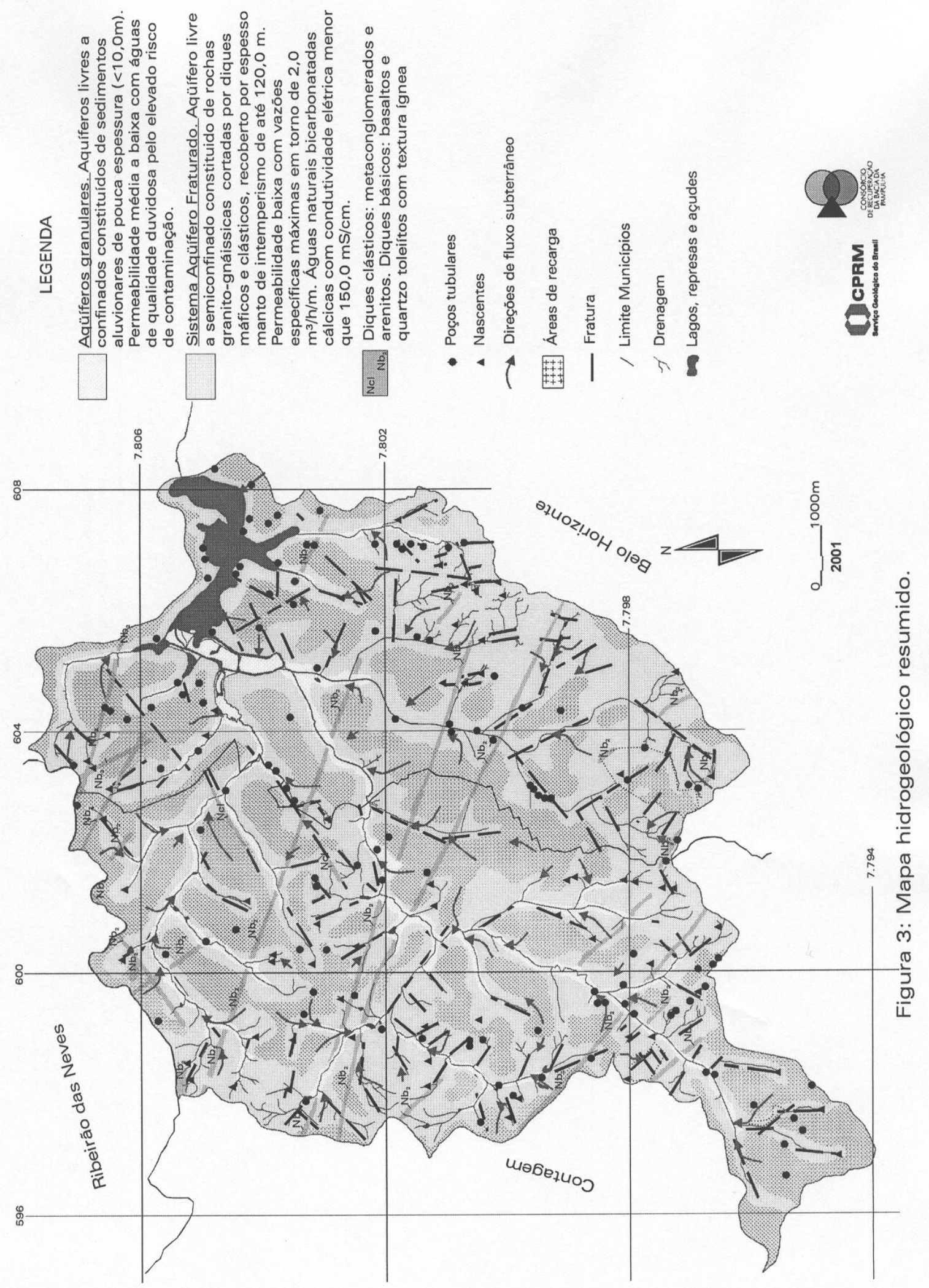


O solo residual é argilo-arenoso no horizonte superficial, passando a silto-arenoso no subsolo. Sua elevada espessura, possivelmente, é conseqüência da antiguidade das rochas, de idade Arqueana

(cerca de 2,8 Ga), em ambiente tectonicamente estável.

O aqüífero granular também é pobre com vazão específica média de $0,23 \mathrm{~m} / \mathrm{h} / \mathrm{m}$. Por outro lado, é importante para as captações domésticas (poços escavados) e, principalmente, na restituição da água pluvial aos cursos d'água. Também atua na recarga do aqüífero fraturado subjacente.

A transmissibilidade varia entre 0,74 a $35,74 \mathrm{~m}^{2} /$ dia (mediana de $7,62 \mathrm{~m}^{2} / \mathrm{dia}$ ) e a permeabilidade, com $b=40 \mathrm{~m}$, tem mediana de $1,9 \times 10^{-1} \mathrm{~m} / \mathrm{dia}$, correspondente a terrenos areno-siltosos (Custódio, 1983).

O fluxo subterrâneo é fortemente controlado pelo relevo com áreas de recarga nas cotas mais elevadas e de relevo plano. O escoamento se dá em direção aos vales, onde aflora através de nascentes nas cabeceiras e ao longo das drenagens. O nível de base é a Lagoa, na cota 801,14 m.

Os diques básicos de direção noroeste formam barreiras hidráulicas subterrâneas. Portanto, nos locais onde se encontram, existem alterações nas direções preferenciais de fluxo.

A recarga natural se dá pela infiltração de águas pluviais, sobretudo em áreas de topografia plana e com cobertura vegetal. É importante a contribuição da recarga indireta por perdas na distribuição de água potável somados aos de água servida nas redes de esgoto.A recarga por água servida compromete a qualidade das águas como comprovado pela contaminação de poços rasos e nascentes por elementos orgânicos encontrados em efluentes domésticos.

\section{Inventário de pontos d'água}

Os poços tubulares totalizaram 147 , sendo 85 em Belo Horizonte e 62 em Contagem. Concentram-se nas áreas industriais e na orla da Lagoa onde estão diversos clubes de lazer e moradores de elevado poder aquisitivo.

A maioria encontra-se em produção (125) e é destinada ao uso doméstico e industrial. Cerca de $70 \%$ foram perfurados na última década, revelando a recente procura por sistemas alternativos de abastecimento, sobretudo por indústrias e sitiantes.

Os poços são revestidos em aço, $\varnothing$ $150 \mathrm{~mm}$, profundidade mediana de $80 \mathrm{~m} \mathrm{e}$ máxima de $150 \mathrm{~m}$. A maioria capta água do aqüífero fraturado e do manto de intemperismo através de filtros. Os níveis estáticos são rasos com mediana de $8,2 \mathrm{~m}$ (figura 4).

As vazões, em geral, são baixas com valores de até $1,946 \mathrm{~m}^{3} / \mathrm{h} / \mathrm{m}$ que atendem satisfatoriamente a pequenas demandas. As maiores vazões estão associadas a poços locados em direções de fraturas NE, indicando o controle estrutural das vazões.

Os poços escavados encontram-se distribuídos por toda a Bacia, sendo que a orla e fundos de vales concentram o maior numero em razão dos níveis freáticos rasos. São captações geralmente rasas, revestidas de manilhas e com profundidades de 3,0 a $30,0 \mathrm{~m}$. Os níveis têm mediana de $2,8 \mathrm{~m}$, atingindo até $21,5 \mathrm{~m}$ em topos de morros. Apresentam-se vulneráveis a contaminação pela proximidade aos corpos d'água poluídos.

As nascentes ocorrem em áreas de quebra acentuada de relevo e ao longo das drenagens. $O$ inventário identificou 69 nascentes perenes e as sub-bacias dos córregos Sarandi e Água Funda concentram o maior número (64\%) em razão da maior área de drenagem e de serem pouco urbanizadas.

Apresentam vazões de até $5 \mathrm{~m}^{3} / \mathrm{h}$, dependendo das condições morfológicas do terreno e da cobertura vegetal nas cabeceiras. Por serem pontos de afloramento dos níveis mais superficiais dos aqüíferos, são fortemente influenciadas pelas ocupações dos terrenos a montante, como revelado pelos resultados hidroquímicos e mudança para regimes intermitentes.

Algumas estão em áreas urbanas e, apesar da inexistência de cobertura vegetal, são perenes e relacionadas com favoráveis condições de recarga pluvial acrescida de recarga indireta.

Notou-se a prática de aterrá-las com lixo e entulho de "bota-foras" com o objetivo de aproveitar o terreno. Essa prática ocorre, principalmente, em áreas de ocupação desordenada, como vilas e favelas, onde 0 problema do espaço é crítico. 


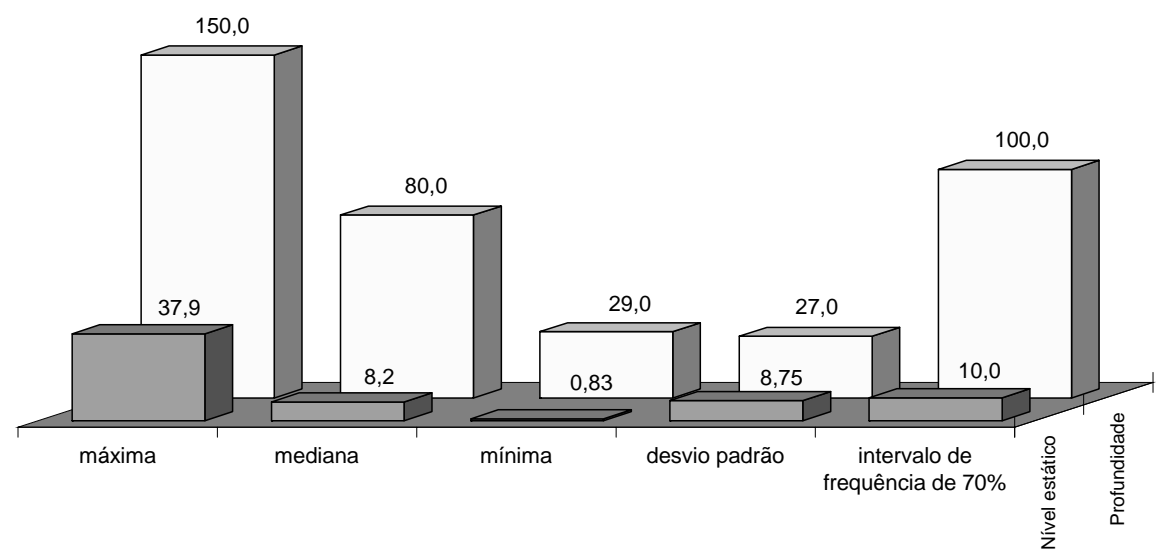

Figura 4: Estatística da profundidade e nível estático dos poços tubulares (m).

\section{Uso das águas subterrâneas}

As águas subterrâneas são pouco explotadas em decorrência do eficiente sistema de abastecimento público. Todavia, na última década, notou-se o crescimento considerável no número de poços tubulares (70 \% datam desse período). Isso se deve às indústrias, aos sitiantes e aos clubes que demandam maior consumo de água e procuram alternativas de abastecimento próprio por questões econômicas diversas, como é tendência atual.

Os principais usos estão de acordo com a natureza da captação e o volume estimado de água retirada dos aqüíferos é de aproximadamente $130.000 \mathrm{~m}^{3} / \mathrm{mês}$. As nascentes são utilizadas para dessedentação animal e pequenas irrigações. Os poços tubulares são utilizados em pequenas irrigações, lavagem automotiva em postos de serviço, clubes de lazer e, principalmente, em indústrias. Os poços escavados são utilizados no abastecimento doméstico e pequenas irrigações.

\section{HIDROQUÍMICA}

As águas subterrâneas naturais são do tipo bicarbonatadas cálcicas-sódicas, neutras $(\mathrm{pH}$ médio de 7,0$)$ e pouco mineralizadas (CE média de $122 \mu \mathrm{S} / \mathrm{cm}$ ).
As águas provenientes das áreas com alto risco de contaminação podem ser bicarbonatadas cálcicas e/ou sódicas, nitratadas cálcicas ou sódicas e até cloretadas sódicas, ácidas a levemente ácidas ( $\mathrm{pH}$ médio de 6,5) e medianamente mineralizadas (CE média de $231 \mu \mathrm{S} / \mathrm{cm}$ ).

Também ocorrem águas bicarbonatadas cálcicas-sódicas, medianamente mineralizadas (CE média de $147 \mu \mathrm{S} / \mathrm{cm}$ ) e com a presença significativa de algum íon anômalo ( $\mathrm{Cl}$, Fe e/ou $\left.\mathrm{NO}_{3}\right)$.

A figura 5 representa graficamente os principais íons presentes nas águas. As maiores diversidades em teores ocorrem nas amostras provenientes de nascentes e poços escavados. De maneira geral, os íons principais não apresentam valores excessivamente altos, mas, em águas contaminadas, divergem consideravelmente do background.

A condutividade elétrica, o pH e a temperatura medidos in loco durante 0 cadastramento, também revelaram a diversidade de tipos de água, com a CE variando entre 20,1 e $2.030 \mu \mathrm{S} / \mathrm{cm}$ (mediana de $138,0 \mu \mathrm{S} / \mathrm{cm})$, pHs entre 3,6 e 9,19 (mediana de 6,48) e temperaturas entre 16,9 e $30,5^{\circ} \mathrm{C}$ (mediana de $24,4^{\circ} \mathrm{C}$ ). Os maiores valores de condutividade foram obtidos nos aterros sanitários e relacionados com contaminação do lençol freático. 

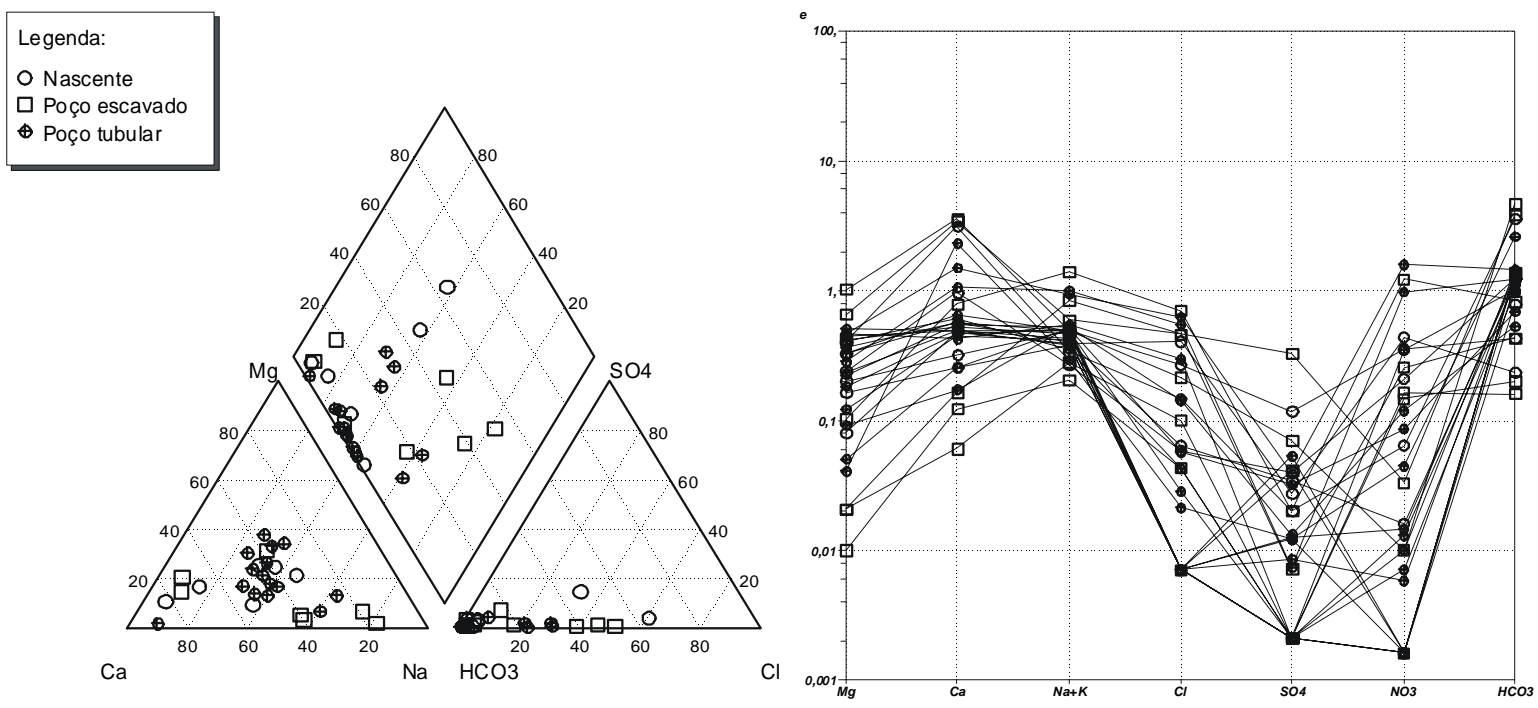

Figura 5: Diagramas de Piper e Schoeller das águas subterrâneas amostradas.

Os principais elementos de origem litológica são $\mathrm{Ca}, \mathrm{Mg}, \mathrm{Na}$ e $\mathrm{K}$ presentes nos minerais que constituem os granitosgnaisses e diques básicos. Quanto aos elementos traços, destacam-se Fe, Mn e P presentes nos minerais das rochas, principalmente nos diques básicos, como piroxênios, óxidos e apatita. Os teores esperados desses elementos nas águas naturais (nascentes) são baixos, pois tratamse de águas de circulação rasa, com pouco tempo de residência em terrenos bastante lixiviados. Portanto, teores acima do background podem estar relacionados com contaminação.

A tabela 2 mostra as estatísticas das análises realizadas. Nota-se a variação, às vezes signifi-cativa, entre os íons principais, presença de contaminantes orgânicos e ausência de metais pesados.

$\mathrm{O}$ ânion predominante é o $\mathrm{HCO}_{3} \mathrm{com}$ até $285,9 \mathrm{mg} / \mathrm{L}$ e mediana de $74,8 \mathrm{mg} / \mathrm{L}$, seguido de $\mathrm{Cl}$ com até $24,6 \mathrm{mg} / \mathrm{L}$ (mediana de $2,0 \mathrm{mg} / \mathrm{L}$ ). $\mathrm{O} \mathrm{SO}_{4}$ ocorre com valores baixos, mediana de $0,6 \mathrm{mg} / \mathrm{L}$, exceto no ponto $199 \mathrm{com} 15,7 \mathrm{mg} / \mathrm{L}$ e relacionado com contaminação.

O cátion que prevalece é o Ca com até $70,8 \mathrm{mg} / \mathrm{L}$ (mediana de $8,8 \mathrm{mg} / \mathrm{L}$ ), seguido do $\mathrm{Na}$ com até $23,7 \mathrm{mg} / \mathrm{L}$ (mediana de 10,1 $\mathrm{mg} / \mathrm{L}$ ). $\mathrm{K} \mathrm{e} \mathrm{Mg}$ apresentaram medianas de 2,9 e 2,1 mg/L.

Dentre os elementos menores, destaca-se a presença, muitas vezes elevada e até excessiva, do Fe com até $17,46 \mathrm{mg} / \mathrm{L}$ (mediana de 0,67 mg/L), Mn com até $0,47 \mathrm{mg} / \mathrm{L}, \mathrm{NO}_{3}$ com até 49,17 (mediana de 1,20 $\mathrm{mg} / \mathrm{L}$ ), Al com até 13,88 $\mathrm{mg} / \mathrm{L}, \mathrm{P}$ com até $0,125 \mathrm{mg} / \mathrm{L}$ e $\mathrm{Br}$ com até $0,91 \mathrm{mg} / \mathrm{L}$. Si ocorre com teores de até 40,0 $\mathrm{mg} / \mathrm{L}$ (mediana de 14,25 mg/L).

A tabela 3 mostra a seleção dos melhores coeficientes de correlação entre os diversos elementos analisados. Não existem boas correlações entre os íons principais e as melhores correlações $(\geq 0,7)$ estão entre os contaminantes. Isso sugere tratar-se de elementos que ocorrem associados nas cargas contaminantes e em condições físico-químicas comuns.

A condutividade elétrica não apresentou boa correlação com contaminantes, mas é bom indicativo de anomalias de qualidade quando se observa que pontos com elevadas contaminações foram os que apresentaram as maiores condutividades.

Os histogramas de freqüência de $\mathrm{Cl}$, $\mathrm{SO}_{4}, \mathrm{Na}, \mathrm{Fe}, \mathrm{NO}_{3}, \mathrm{~N}$-orgânico, STD e $\mathrm{Si}$ indicaram valores predominantemente baixos (figura 6). Valores acima das maiores freqüências (background) estão relacionados com contaminação.

As águas superficiais naturais são pouco expressivas na Bacia e as únicas amostras provenientes de áreas menos degradadas são dos pontos PP-9 e PP-11 (figura 7) que drenam áreas rurais. São águas bicarbonatadas cálcicas-sódicas, $\mathrm{pH}$ levemente ácido e pouco mineralizadas (CE média de 82,5 $\mu \mathrm{S} / \mathrm{cm}$ ). Têm composições similares às águas subterrâneas, já que são originárias da restituição natural das águas dos aqüíferos superficiais. Os resultados 
estatísticos dos principais tributários e afluentes da Lagoa estão relacionados na tabela 2.

As águas superficiais contaminadas apresentam uma diversidade de composição aquém do esperado, considerando o elevado potencial contaminante existente. Os resultados indicaram que predominam baixos teores dos íons principais e metais pesados. Foram elevados os elementos associados à carga orgânica de efluentes ( $\mathrm{N}$ e P). Quanto aos elementos traços destacam-se o Fe, Mn e Al.

A qualidade das águas subterrâneas considerou os padrões de águas destinadas ao consumo humano da portaria 36/90 do Ministério da Saúde e para os parâmetros que não constam utilizou-se a portaria 1003/76 - resolução 25 para águas minerais e naturais de fonte.

Tabela 2: Resultados estatísticos das amostras de águas subterrâneas.

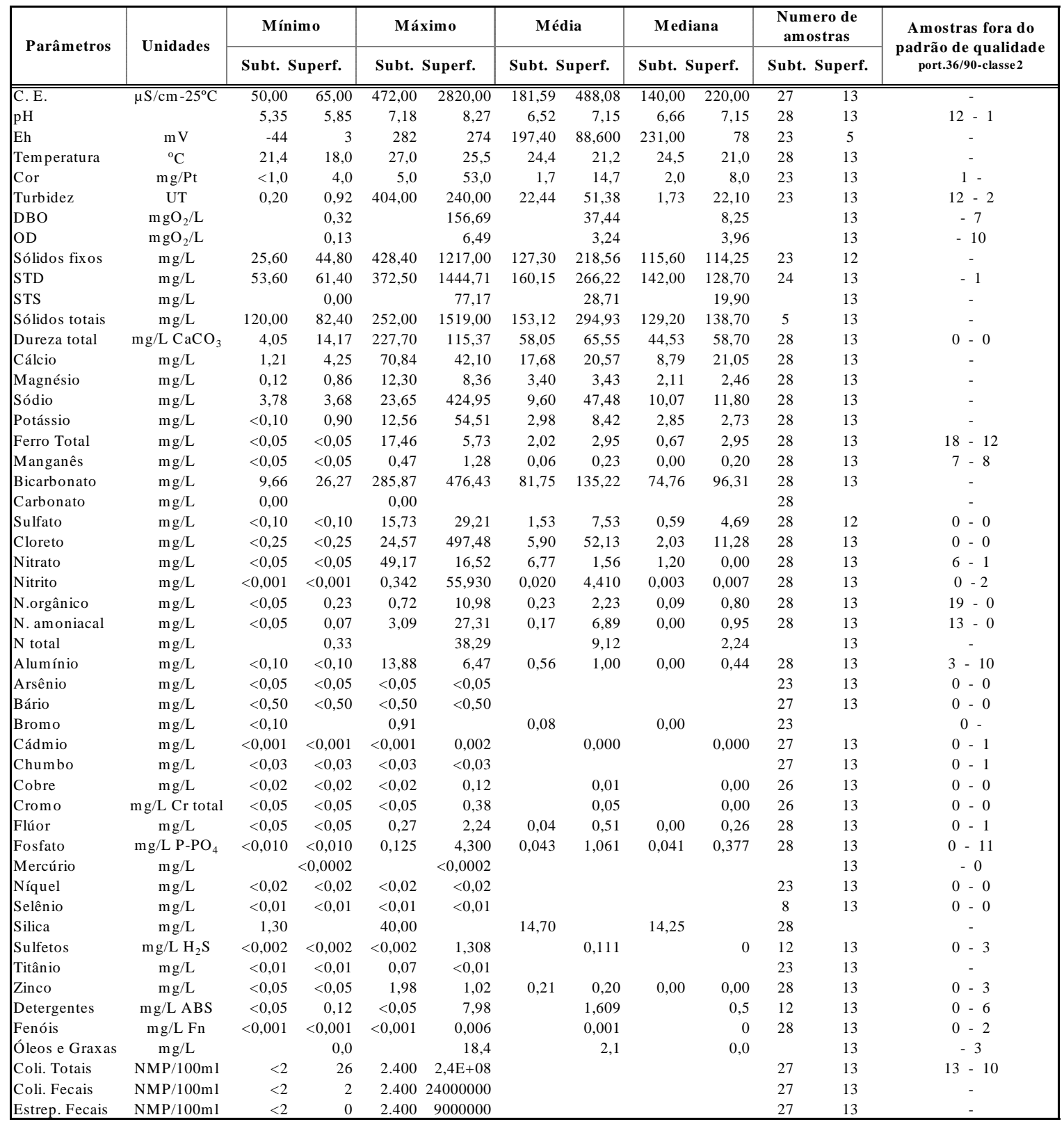


Tabela 3: Melhores coeficientes de correlação entre os elementos analisados.

\begin{tabular}{|c|c|c|c|c|c|c|c|c|c|c|c|}
\hline & Cond & $\mathrm{HCO} 3$ & $\mathrm{Cl}$ & $\mathrm{Na}$ & $\mathrm{Mg}$ & $\mathrm{Fe}$ & Mn & $\mathrm{NO3}$ & $\mathrm{Br}$ & $\mathrm{Al}$ & NAmon \\
\hline Cond & $\overline{1}$ & 0,879 & 0,463 & 0,216 & 0,675 & 0,462 & 0,700 & 0,269 & 0,652 & 0,532 & 0,611 \\
\hline $\mathrm{HCO} 3$ & & 1,000 & 0,044 & $-0,087$ & 0,760 & 0,621 & 0,627 & $-0,170$ & 0,764 & 0,614 & 0,679 \\
\hline $\mathrm{Cl}$ & & & 1,000 & 0,753 & 0,077 & $-0,110$ & 0,409 & 0,838 & 0,059 & 0,037 & 0,098 \\
\hline $\mathrm{Na}$ & & & & 1,000 & 0,007 & $-0,107$ & 0,324 & 0,730 & $-0,083$ & $-0,062$ & $-0,016$ \\
\hline Mg & & & & & 1,000 & 0,674 & 0,539 & $-0,063$ & 0,712 & 0,631 & 0,664 \\
\hline $\mathrm{Fe}$ & & & & & & 1,000 & 0,648 & $-0,211$ & 0,895 & 0,801 & 0,800 \\
\hline Mn & & & & & & & 1,000 & 0,247 & 0,760 & 0,750 & 0,805 \\
\hline NO3 & & & & & & & & 1,000 & $-0,161$ & $-0,104$ & $-0,079$ \\
\hline $\mathrm{Br}$ & & & & & & & & & 1,000 & 0,974 & 0,982 \\
\hline Al & & & & & & & & & & 1,000 & 0,987 \\
\hline NAmon & & & & & & & & & & & 1,000 \\
\hline
\end{tabular}
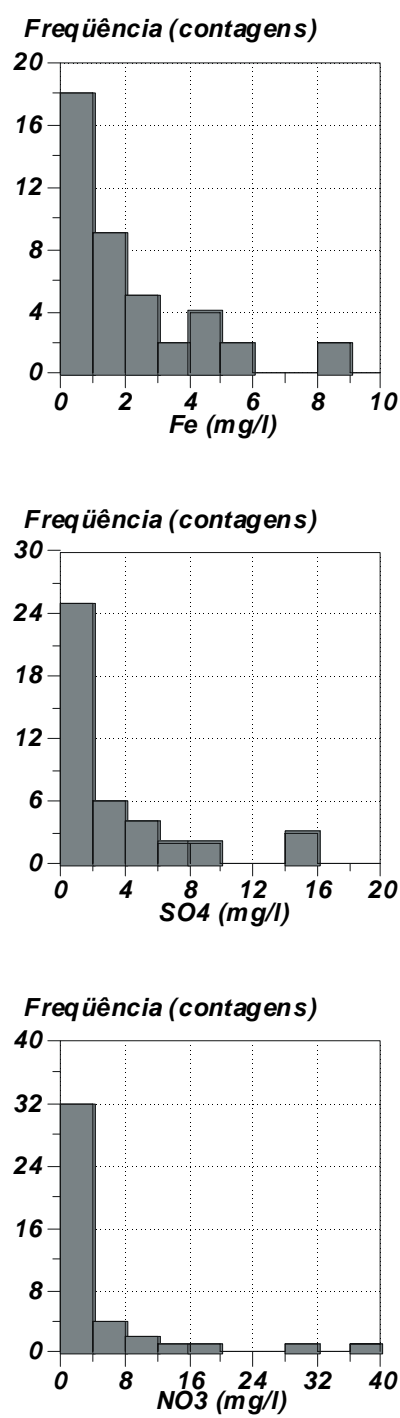
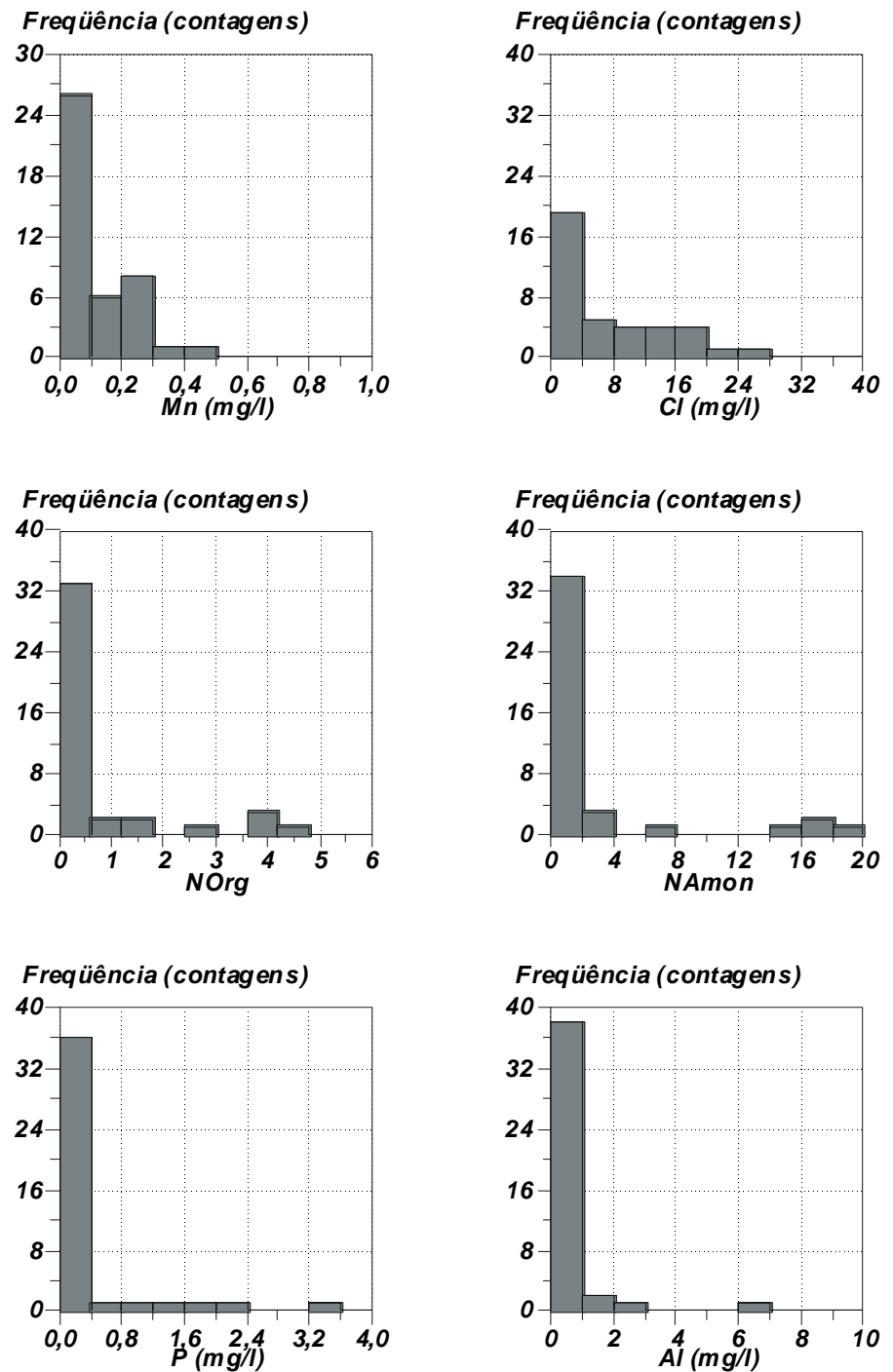

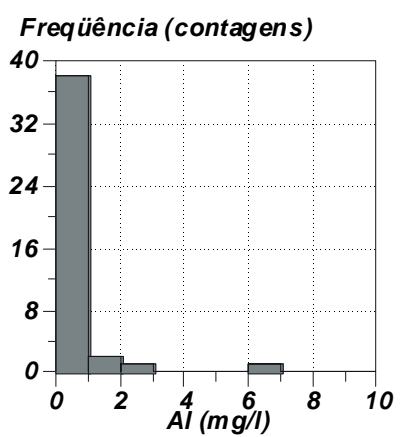

Figura 6: Freqüência dos principais elementos relacionados com contaminação.

As análises apresentaram um ou mais parâmetros acima do permitido pela legislação e os mais freqüentes estão relacionados na tabela 2 .

Os contaminantes mais comuns são $\mathrm{N}$-orgânico e amoniacal e $\mathrm{NO}_{3}$ que foram anômalos em 23 amostras. Fe e Mn ocorrem em 20 amostras e coli. totais, fecais ou 60 estreptococos fecais em 16. Alumínio é relativamente alto em três pontos que apresentaram contaminação por outros elementos.

Dentre os pontos contaminados, destacam-se 57, 115, 154, 158, 199, 234 e 246 (figura 7) pela quantidade de parâmetros e, de vezes, acima dos limites. 
São pontos próximos a fontes com alta carga contaminante como os córregos Coqueiros (199), Água Funda (57), Ressaca (158) e Mergulhão (115), e dentro de áreas urbanizadas próximos à rede de esgoto (154, 234 e 246).

Em alguns locais, os resultados anômalos apresentaram-se excessivamente altos, com teores de $\mathrm{NO}_{3}$ entre 49,14 e
$30,12 \mathrm{mg} / \mathrm{L}$ (limite de $10 \mathrm{mg} / \mathrm{L}$ ) nos pontos 234, 154 e 158. O Fe é o contaminante mais comum com valores entre 17,46 e $8,70 \mathrm{mg} / \mathrm{L}$ (limite de 0,3 mg/L) nos ponto 115, 133 e 67 . O Al atinge até $13,47 \mathrm{mg} / \mathrm{L}$ (limite de 0,2 $\mathrm{mg} / \mathrm{L})$ no ponto 68 . Os coliformes totais alcançam entre 2.400 e $1.600 \mathrm{NMP} / 100 \mathrm{~mL}$ nos pontos 121, 115, 154 e 176. 
Rev. Águas Subterrâneas nํ17/ Maio 2003.
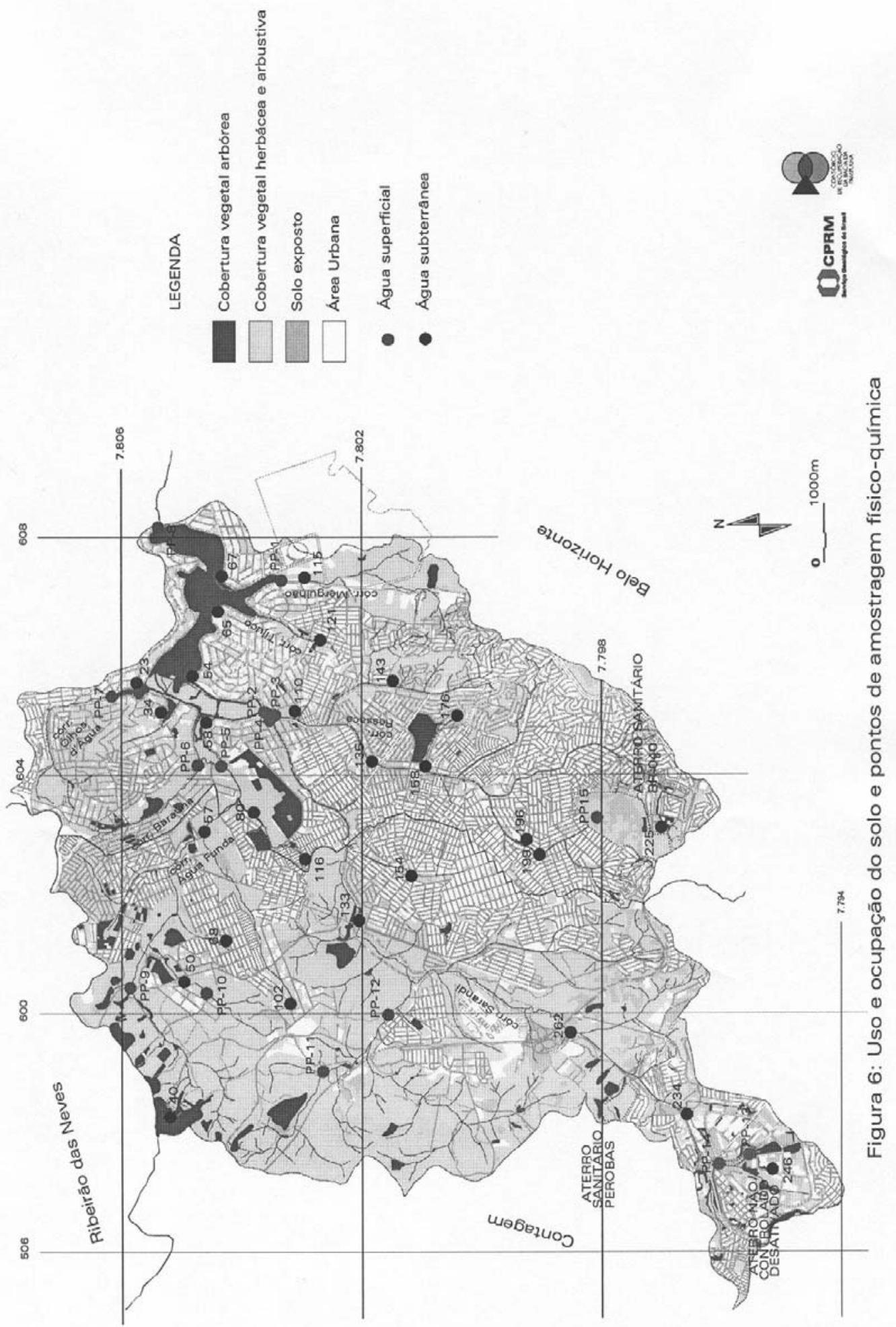
Outros elementos associados a atividades industriais como fenóis e metais pesados ( $\mathrm{Cu}, \mathrm{Ni}, \mathrm{Pb}, \mathrm{Cr}, \mathrm{Se}, \mathrm{Cd}, \mathrm{Ba}$ e As) não foram detectados, o que não significa que estejam ausentes em locais com elevadas cargas contaminantes industriais ou de resíduos sólidos. Isso se deve a pouca mobilidade dos elementos no subsolo, ficando retidos até condições limites de saturação.

Resultados do monitoramento ambiental do aterro da BR-040 revelaram altos teores de metais pesados, entre outros contaminantes, presentes nas águas subterrâneas, com destaque para $\mathrm{Cd}, \mathrm{Pb}$, $\mathrm{Al}, \mathrm{Ba}, \mathrm{Fe}, \mathrm{Mn}, \mathrm{Hg}$ e $\mathrm{Zn}$. Os resultados revelam que o subsolo já está contaminado e a pluma migrando além dos seus limites, como indicaram os estudos geofísicos.

A avaliação da qualidade das águas superficiais considerou somente uma amostragem no fim do período de chuvas. A tabela 2 relaciona os parâmetros acima dos limites permitidos pela legislação do CONAMA para classe 2 .

Os elementos anômalos mais comuns são: OD, DBO, Fe, Mn, P, Al, coliformes e detergentes. $\mathrm{Cu}, \mathrm{Zn}$ e $\mathrm{S}$, e óleos e graxas e fenóis ocorrem localmente associados com efluentes industriais.

Os cursos d'água mais contaminados são os córregos Bitácula (PP-14), Beatriz
(PP-13), Sarandi (PP-4), Ressaca (PP-3), Água Funda (PP-5) e Mergulhão (PP-1) mostrados na figura 6 . O cór. Bitácula drena o chorume do aterro desativado de Contagem e é significativo o incremento de todos os elementos analisados a jusante do aterro, indicando que se trata de um perigoso foco de contaminação para as águas superficiais e subterrâneas. Os outros córregos drenam áreas urbanas e recebem parte dos efluentes domésticos e industriais de praticamente toda a Bacia.

A DBO varia de 156,7 a 61,0 mg/L nos córregos Beatriz, Bitácula, Sarandi, Ressaca e Mergulhão (limite $5,0 \mathrm{mg} / \mathrm{L}$ ). O OD é baixo em todos os tributários, atingindo $0,5 \mathrm{mg} / \mathrm{L}$ no Ressaca e Sarandi (limite $>5,0 \mathrm{mg} / \mathrm{L}$ ). $\mathrm{O}$ $P$ total estava entre 4,3 e $2,2 \mathrm{mg} / \mathrm{L}$ nos córregos Bitácula, Beatriz e Ressaca (limite $0,025 \mathrm{mg} / \mathrm{L})$. Os detergentes apresentaram valores entre 8,0 e 2,4 mg/L (limite 0,2 mg/L) nos córregos Bitácula, Beatriz, Ressaca e Mergulhão. Óleos e graxas atingiram 18,4 $\mathrm{mg} / \mathrm{L}$ no cór. Bitácula (limite é a ausência).

A tabela 4 indica os melhores coeficientes de correlação entre os diversos elementos analisados. Existem boas correlações $(\geq 0,7)$ entre todos os contaminantes, indicando fontes e condições físico-químicas semelhantes.

Tabela 4: Melhores coeficientes de correlação entre contaminantes em águas

\begin{tabular}{|c|c|c|c|c|c|c|c|c|c|c|c|}
\hline & $\mathrm{Na}$ & $\mathrm{Cl}$ & SO4 & Cond & BOD & NO3 & NO2 & $\mathbf{P}$ & ABS & NAmon & Coli Total \\
\hline $\mathrm{Na}$ & $\bar{~} 1$ & 0,999 & 0,855 & "0,981 & 0,777 & "0,988 & "0,994 & $0,0,735$ & "0,876 & $0,0,425$ & 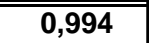 \\
\hline $\mathrm{Cl}$ & & 1 & 0,869 & 0,987 & 0,797 & 0,984 & 0,990 & 0,758 & 0,887 & 0,456 & 0,995 \\
\hline SO4 & & & 1 & 0,916 & 0,904 & 0,779 & 0,805 & 0,876 & 0,850 & 0,702 & 0,876 \\
\hline Cond & & & & 1 & 0,871 & 0,949 & 0,958 & 0,841 & 0,925 & 0,578 & 0,977 \\
\hline BOD & & & & & 1 & 0,699 & 0,715 & 0,955 & 0,925 & 0,807 & 0,778 \\
\hline NO3 & & & & & & 1 & 0,994 & 0,656 & 0,837 & 0,323 & 0,977 \\
\hline NO2 & & & & & & & 1 & 0,666 & 0,845 & 0,334 & 0,987 \\
\hline $\mathbf{P}$ & & & & & & & & 1 & 0,891 & 0,913 & 0,730 \\
\hline ABS & & & & & & & & & 1 & 0,643 & 0,858 \\
\hline NAmon & & & & & & & & & & 1 & 0,429 \\
\hline Coli Total & & & & & & & & & & & 1 \\
\hline
\end{tabular}

superficiais.

O Índice de Qualidade de Águas-IQA (CETESB, 1985), também demonstra que as águas que aportam na Lagoa estão com qualidade muito ruim a média e as poucas com qualidade boa situam-se nas áreas rurais no extremo noroeste da bacia (PP-09 e PP-11, figura 7).

\section{Fontes potenciais de poluição}

As principais fontes potenciais de contaminação dos recursos hídricos da Bacia são a precária infra-estrutura de saneamento e a disposição inadequada de resíduos sólidos (aterros) e líquidos (postos de serviço e oficinas). Também é importante a rede de esgoto que apresenta fugas de difícil identificação. São fontes dispersas por toda a Bacia, principalmente nas áreas urbanas e industriais.

A elevada densidade populacional e a falta de saneamento eficiente geram lixo e efluentes que são lançados na rede de drenagem formando uma carga contaminante de distribuição ampla e linear. As atividades industriais irregulares também geram efluentes que são lançados nos cursos d'água ou resíduos que são dispostos no próprio empreendimento e 
lixiviados em períodos de chuva. Isso contamina os aqüíferos subjacentes e os situados ao longo dos vales, influenciados pelo regime do curso d'água (efluente ou influente), e por fim degrada a qualidade da água da Lagoa.

As atividades industriais na Bacia são diversificadas e concentram-se principalmente no Centro Industrial de Contagem (CINCO). São indústrias de bebidas, alimentares, de transformação de plásticos e produtos metalúrgicos, fabricação de concreto e pré-moldados, artefatos de aço, estruturas metálicas, mecânicas, químicas, lavanderias, além de diversas outras pequenas atividades nãoidentificadas e, às vezes, de elevado potencial poluente.

Existem três grandes aterros de resíduos sólidos. Dois são controlados e outro que atualmente está desativado, não era controlado. $O$ aterro que recebe o maior volume de resíduos (BR-040) pertence à prefeitura de Belo Horizonte e encontra-se próximo do seu limite de armazenamento.

Em Contagem, o aterro sanitário Perobas entrou em operação no fim de 1996 e o antigo depósito ("lixão") operou até 1997, recebendo todo o lixo industrial, doméstico e hospitalar do município, e não foi recuperado adequadamente.

Ensaios de geofísica a jusante dos aterros da BR-040 e desativado, apontaram níveis rasos de material condutivo sendo fortes indícios de contaminação do subsolo. Os indícios são reforçados pela presença de metais pesados em análises de água subterrânea no aterro da BR-040, e elevada carga contaminante no córrego Bitácula que drena o aterro desativado.

Os resultados revelaram contaminantes dispersos por toda a Bacia, tanto em subsuperfície (nascentes e poços escavados), como em profundidade (poços tubulares, provavelmente mal construídos). Apesar disso, os aqüíferos não estão definitivamente contaminados, mas em locais de risco, este processo já está em franco desenvolvimento. $O$ risco de contaminação resulta da capacidade de infiltração do solo relativamente boa $(k \approx 0,19$ $\mathrm{m} / \mathrm{dia}$ ) associada à elevada carga de contaminantes, principalmente da rede de esgoto precária e dos cursos de água poluídos.

A avaliação da qualidade das águas superficiais revelou que a maioria dos cursos d'água está contaminada e que além de degradarem a Lagoa, contaminam os lençóis freáticos rasos ao longo dos vales. Sem dúvida, a origem desta contaminação é o saneamento precário.

Vale lembrar do passivo contaminante existente nos sedimentos aluvionares e no subsolo decorrente do acumulo de efluentes após longo período sem saneamento.

\section{USO E OCUPAÇÃO DO SOLO}

O uso e ocupação do solo foi elaborado a partir de fotografias aéreas de 1994 e 1995. A figura 8 quantifica os resultados a partir do mapa de Uso e Ocupação do Solo de 1995 (figura 7). Ainda que parcialmente desatualizados, os valores indicam a importância das áreas ainda nãourbanizadas no município de Contagem. São áreas importantes para a preservação dos recursos hídricos com diversas nascentes associadas às zonas de campo e mata que podem e devem ser preservadas. O mapa também mostra as áreas com solo exposto que, por serem fontes de sedimentos para os cursos d'água e para a Lagoa, devem ser recuperadas. 


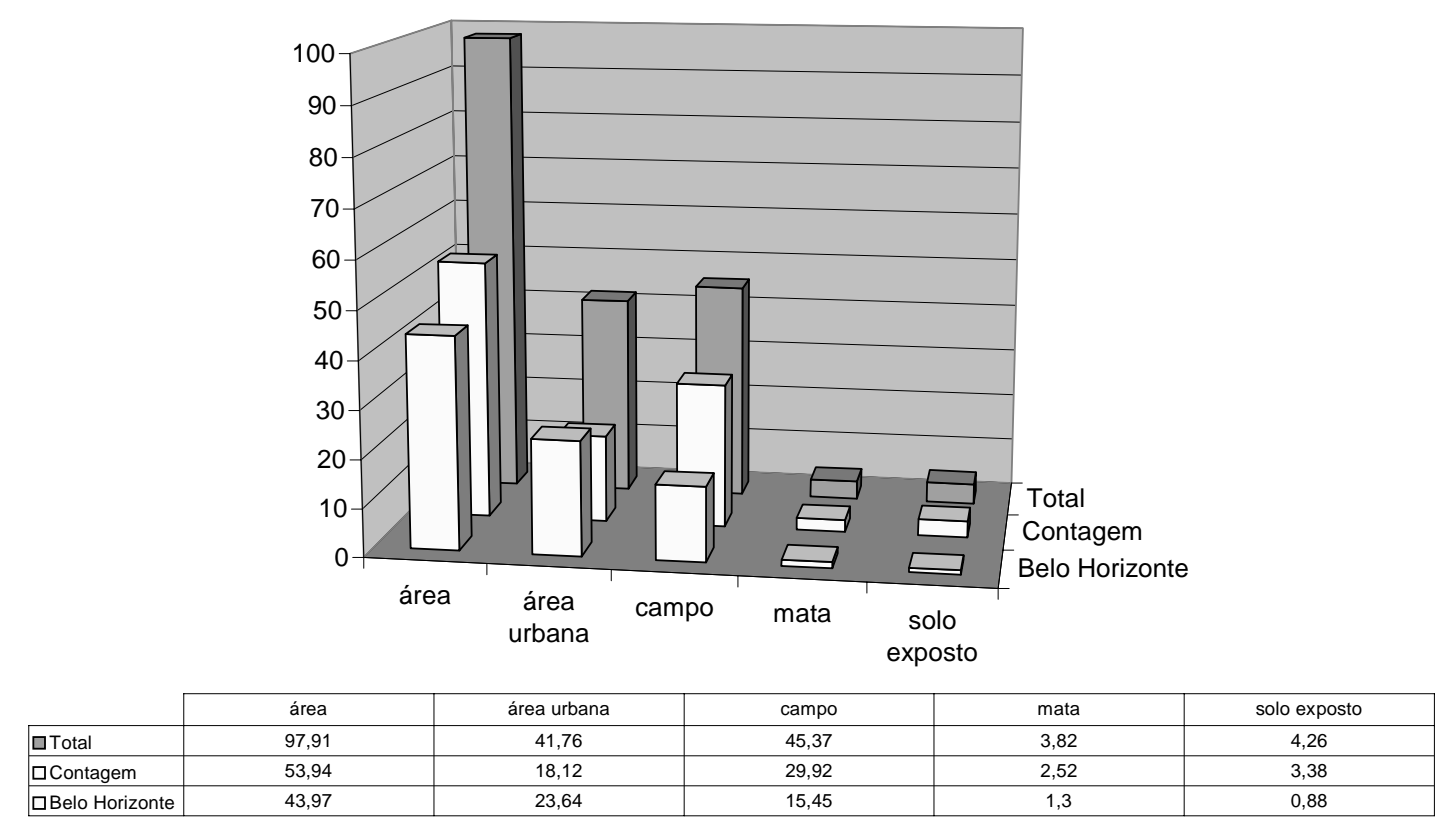

Figura 8: Uso e ocupação do solo.

\section{ÁREAS DE PRESERVAÇÃO DOS RECURSOS HÍDRICOS}

A delimitação considerou as áreas de recarga e os aspectos legais do Código Florestal Brasileiro, uma vez que as legislações municipais não tratam especificamente das áreas de proteção dos recursos hídricos.

As áreas de preservação foram determinadas a partir do estabelecimento de uma faixa de 30 metros ao longo de todas as drenagens, lagos e açudes e 50 metros de raio no entorno das nascentes, como determina a Lei 4.771 do Código Florestal Brasileiro no seu Parágrafo $2^{\circ}$. São áreas importantes para a manutenção das funções hidrológicas das matas ciliares (estabilização de áreas críticas, tampão e filtro de nutrientes e retenção de sedimentos) como comprovado em diversos estudos (Lima, 2000).

Em 1995, as áreas marginais aos cursos d'água e nascentes perfaziam 12,3 $\mathrm{km}^{2}$, sendo $3,7 \mathrm{~km}^{2}$ de áreas urbanizadas por avenidas, canais ou construções e 8,6 $\mathrm{km}^{2}$ de áreas de mata e campo que poderiam ser recuperadas ou preservadas segundo a Lei Federal 4.771. Essas áreas alcançavam mais que o dobro das áreas de matas arbóreas existentes na época.

Isso revela que, apenas seguindo o que determina o Código Florestal Brasileiro, ainda é possível criar considerável área de preservação, distinta da função de parques, importante para a manutenção dos cursos d'água, da qualidade e da quantidade da água de renovação da Lagoa, além de aspectos biológicos, de lazer e outros.

Outros limites de áreas de preservação são as de recarga dos aqüíferos nos terrenos de menor declividade (< 30\%). Apesar do sistema aqüífero ter recarga em toda a área (aqüífero livre e homogêneo), essas áreas foram consideradas como de restrição às ocupações sem saneamento, instalações com elevado potencial poluente e loteamentos com áreas mínimas de infiltração.

A indicação de áreas de preservação, ou restrição de determinados tipos de ocupação, se justifica pelo potencial de crescimento urbano que a Bacia apresenta. No município de Contagem, que ainda possui áreas não ocupadas, grande parte da bacia está contida na Zona de Expansão Urbana 1, que permite a ocupação de lotes de até $360 \mathrm{~m}^{2}$. Somente algumas poucas áreas restringem a ocupação com lotes de até $1.000 \mathrm{~m}^{2}$, mesmo assim, sujeito a maior adensamento sob condições de saneamento favoráveis.

Em Belo Horizonte, o quadro não é diferente, e as poucas áreas de preservação ambiental, proteção e de ocupação restrita, sofrem pressões constantes para que se modifiquem as restrições. 


\section{CONCLUSÕES}

- O sistema aqüífero da Bacia é do tipo livre a semiconfinado, constituído de rochas granito-gnáissicas fraturadas recobertas por espesso manto de intemperismo com até $120 \mathrm{~m}$. Os fraturamentos mais produtivos são os de direção NE com bom potencial para captações que demandem pequenos volumes de água (vazões menores que 50 $\left.\mathrm{m}^{3} / \mathrm{h}\right)$.

- A maior parte dos 147 poços tubulares profundos é de uso industrial e doméstico, sendo $70 \%$ perfurados na última década. Esse incremento tende a continuar devido a crescente demanda de consumo de água "privada" por parte das indústrias, sitiantes e clubes.

- Das 69 nascentes perenes identificadas, $64 \%$ concentram-se nas subbacias dos córregos Sarandi e Água Funda em razão das áreas verdes que ainda restam, cerca de $70 \%$ do existente. As vazões de até $5 \mathrm{~m}^{3} / \mathrm{h}$ dependem das condições morfológicas do terreno e da cobertura vegetal nas cabeceiras. As nascentes encontram-se ameaçadas pela ocupação urbana e pelo lançamento de esgoto doméstico e industrial nas cabeceiras dos cursos de água. A permanência desses mananciais é imprescindível para a perenização dos cursos d'água e a renovação natural da água da Lagoa.

- As águas subterrâneas naturais são do tipo bicarbonatadas cálcicas-sódicas, neutras (pH médio de 7,0) e pouco mineralizadas (CE média de $122 \mu \mathrm{S} / \mathrm{cm}$ ). Já as águas contaminadas podem ser bicarbonatadas cálcicas e/ou sódicas, nitratadas cálcicas ou sódicas e até cloretadas sódicas, ácidas a levemente ácidas ( $\mathrm{pH}$ médio de 6,5) e mais mineralizadas (CE média de $231 \mu \mathrm{S} / \mathrm{cm}$ ).

- Os contaminantes mais comuns são os $\mathrm{N}$ orgânico e amoniacal, $\mathrm{NO}_{3}, \mathrm{Fe}, \mathrm{Mn}$ e coliformes. Os metais pesados são de ocorrência pontual e relacionados com aterros sanitários.

- O risco de contaminação dos aqüíferos resulta da capacidade de infiltração do solo associada à elevada carga hidráulica de contaminantes nos cursos d'água poluídos e com saneamento precário. Quanto às fontes potenciais, destacam-se a disposição inadequada de resíduos industriais, armazenamento de combustíveis, oficinas mecânicas e lixiviação de aterros de resíduos.
- As águas superficiais encontram-se bastante degradadas com valores bem acima do permitido para águas da classe 2 . Os parâmetros irregulares são OD, DBO, $\mathrm{Fe}, \mathrm{Mn}, \mathrm{P}, \mathrm{Al}$, coliformes e detergentes. Metais pesados ocorrem localmente e relacionados com efluentes industriais. Os cursos d'água mais contaminados são os córregos Bitácula, Beatriz, Sarandi, Ressaca, Água Funda e Mergulhão.

- Os resultados hidroquímicos indicaram que os recursos hídricos da Bacia estão em franco processo de deterioração da qualidade. As águas superficiais já se encontram bastante comprometidas e é preocupante a situação das subterrâneas que apresentaram indícios de contaminação em diversos locais. Apesar disso, não se deve considerar que os aqüíferos da Bacia estejam definitivamente contaminados e sim que, em locais de risco, este processo já esteja em franco desenvolvimento.

- O uso e ocupação do solo como vem sendo implementado é, sem dúvida, o grande responsável pela deterioração dos recursos hídricos. Em 1995, a área urbana ocupava $41,8 \mathrm{~km}^{2}$ e a área verde (cobertura vegetal arbórea, arbustiva e campo) 49,2 $\mathrm{km}^{2}$, sendo que a maior parcela de área verde (66\% do total) localizava-se no município de Contagem, nas áreas correspondentes às cabeceiras da bacia. As áreas verdes eram e ainda são as responsáveis pela existência de mananciais não-contaminados, embora hoje sejam poucos.

- O aumento na densidade populacional como estabelecido nos planos diretores atuais causará o desmatamento, desnudamento do solo e impermeabilização do terreno, ocupação das várzeas, modificação da rede de drenagem com canalização dos córregos, etc. As conseqüências serão o aumento do pico das cheias e transferência a jusante de todos os prejuízos econômicos e sociais associados, erosão e assoreamento da Lagoa e cursos d'água, aumento na produção de esgoto e lixo dispostos inadequadamente, e contínua e crescente deterioração da qualidade das águas.

- O desrespeito à Lei 4.771 do Código Florestal Brasileiro com a supressão da vegetação ciliar e da sua função hidrológica, comprometerá ainda mais o escoamento de base dos cursos d'água, dificultando a renovação e a recuperação da qualidade da 
Rev. Águas Subterrâneas nํ17/ Maio 2003.

água da Lagoa, além do aumento do processo erosivo que tanto tem custado com dragagens feitas periodicamente na Lagoa. 


\section{REFERÊNCIAS BIBLIOGRÁFICAS}

ABGE-Associação Brasileira de Geologia de Engenharia. Ensaios de Permeabilidade

em Solos: Orientações para sua Execução no Campo. Bol. 4. 3 ed. 30p. jun.1996.

Beato, D.A.C., coord. Estudo Hidrogeológico da Bacia da Pampulha: relatório final. Belo Horizonte: CPRM/PBH, 2001. (Inclui mapas e anexos).

CDTN-Centro de Desenvolvimento da Tecnologia Nuclear. Levantamento EcoBatimátrico da Lagoa da Pampulha; Relatório Técnico. Belo Horizonte: CDTN, 2000.

CETESB Companhia de Tecnologia de Saneamento Ambiental. Técnica de Abastecimento e Tratamento de água. São Paulo, CETESB, 1987.

Custódio, E, Llamas, M. Hidrologia subterrânea. Barcelona: Omega, 1983.2350p.

Lima, W.P. Hidrologia de Matas Ciliares. Matas Ciliares, Conservação e Recuperação. São Paulo: Ed. Da Universidade de São Paulo: Fapesp. p.3344. 2000.

Noce, C.M., Machado, N., Teixeira, W. $\underline{\mathrm{O}}$ Complexo Belo Horizonte e a Evolução Arqueana do Quadrilátero Ferrífero, Minas Gerais. In: 38 CONGRESSO

BRASILEIRO DE GEOLOGIA, 1994, Camboriú. Boletim de Recursos
Expandidos, Porto Alegre. SBG/ DNPM/ CPRM.v.1, p.68-69.

Oliveira, M.G.B., Baptista, M.B. Análise da Evolução Temporal da Produção de Sedimentos na Bacia Hidrográfica da Pampulha e Avaliação do Assoreamento do Reservatório. In: XII Simpósio Brasileiro de Recursos Hídricos, 1997, Vitória. Anais... Vitória: ABRH, 1997.

Peixoto, L.E., Ávila, R.X. de. Saneamento Ambiental de Contagem. Anais do Seminário da Bacia Hidrográfica da Pampulha, p.150-6.1992.

PROPAM - Programa de Recuperação e Desenvolvimento Ambiental da Bacia da Pampulha. Documento Síntese, 1999 Prefeitura Municipal de BH; Prefeitura de Contagem; Secretaria Municipal do Meio Ambiente de BH; Secretaria Municipal do Meio Ambiente de Contagem.

Silva, A.B, Carvalho, E.T., Fantinel, L.M, et al. Estudos Técnicos para o Levantamento dos Focos de Erosão e do Risco Geológico na Bacia Hidrográfica da Lagoa da Pampulha, Belo Horizonte. Belo Horizonte: Convênio PBH/FUNDEP/UFMG, 1994. 45p.

SUDECAP-Superintendência de Desenvolvimento da Capital. Programa de Monitoramento Hidrossedimentométrico da Bacia Hidrográfica da Pampulha. Belo Horizonte: SUDECAP, 1999. 